\title{
Influence of Long-term Chemical fertilizers and Organic Manures on Soil Fertility - A Review
}

\author{
Manoj Kumar Bhatt ${ }^{1, *}$, Rini Labanya ${ }^{1}$, Hem C. Joshi ${ }^{2}$ \\ ${ }^{1}$ Department of Soil Science, College of Agriculture, India \\ ${ }^{2}$ Department of Plant Physiology, College of Basic Sciences and Humanities, India \\ Received June 17, 2019; Revised August 29, 2019; Accepted September 16, 2019
}

Copyright $(2019$ by authors, all rights reserved. Authors agree that this article remains permanently open access under the terms of the Creative Commons Attribution License 4.0 International License

\begin{abstract}
The Effects of Chemical Fertilizers and organic manure on soil fertility focuses primarily on the behavior of nitrogen $(\mathrm{N})$ and phosphorus $(\mathrm{P})$ in soil because these two nutrients are the main nutrients that limit crop yields and they are also the nutrients of particular concern for environmental quality. Besides, potassium (K), sulfur (S), macronutrients (primary and secondary), micronutrient and other elements, salts, and sodium, soil $\mathrm{pH}, \mathrm{EC}$. CEC and organic matter are covered. Organic fertilizer improves physical and biological activities of soil but they have comparatively low in nutrient content, so larger quantity is required for plant growth. However, inorganic fertilizer is usually immediately and fast containing all necessary nutrients that are directly accessible for plants. But continuous use of inorganic fertilizers alone causes soil organic matter degradation, soil acidity, and environmental pollution. So the combined application of inorganic fertilizer and organic manure has an alternative system for the sustainable and cost-effective management of soil fertility. The objective of the present review is to assess the effect of long-term chemical fertilizers and organic manure on soil fertility. The study revealed that the appropriate application of inorganic fertilizers along with organic manure increases soil fertility than the values obtained by organic or inorganic fertilizers separately.
\end{abstract}

Keywords Organic Manure, Inorganic Fertilizer, Long-term Management

\section{Introduction}

Indian agriculture has made tremendous progress after the sixties. The success of agriculture production has been attributed to the widespread use of high yielding varieties. Among several inputs, fertilizers have been the kingpin for the transformation of Indian agriculture from subsistence to surplus. After the resounding success of the green revolution, a decline in the growth rate of food production is seen during the recent past in respect of crop productivity and input use response. Presently, the major concern in agriculture is to arrest any further decline in crop productivity and soil quality. Although high yielding nutrient responsive crop varieties resulted in higher productivity, it led to the overexploitation of soil reserves and other resources. In general, Indian soils are poor infertility, as these have been consistently depleted of their finite nutrient resources due to continuous cultivation for centuries, adoption of modern agricultural technologies, and imbalanced use of fertilizers and poor use efficiency of fertilizers. As a consequence, the food grain production is stagnated at present [60] fertilizer use efficiency refers to the proportion of applied nutrients recovered by the crop (e.g. $\mathrm{kg}$ grain $\mathrm{kg}^{-1}$ of applied nutrient). Recently, a declining trend in rice-wheat productivity has been reported which is a cause of concern to the agricultural scientists and administrators. To give break-through in food grain production, it is necessary to adopt suitable techniques for enhancing the use efficiency of various fertilizers.

The concept of soil quality looks beyond soil fertility and maximum production, the definition stresses the importance of system maintenance [42]. To sustain system maintenance, basic soil quality indicators that can identify soil management problems from the perspective of the soil functions and development are handy to monitor the sustenance of the system. The quality and health of soil determine agricultural sustainability [2] environmental quality [83] and as a consequence of both, plant, animal and human health [38]. About agriculture, the term soil quality has been used to measure soil's fitness to support crop growth without its degradation. It is a critical component of sustainable agriculture and it comprises the combination of physical, chemical and biological 
characteristics that enable the soil to perform a wide range of functions. [48] Proposed soil biological activity, diversity and productivity as vital soil functions. The soil quality mainly gets influenced by the amount and quality of organic carbon which directly dictates biological properties greatly in comparison to chemical and physical ones. Various cropping systems and management practices have a great influence on soil quality parameters [122]. In India, long-term fertilizer experiment was first started in 1885 at Kanpur followed by many other locations at the beginning of the $20^{\text {th }}$ century [72]. The experiments generated valuable information on the effect of organic manure and chemical fertilizers on crop yields, nutrient removal, and soil properties. The long-term field experiments are considered to provide the best practical approximation to a test of the sustainability of farming practices. The long-term fertilizer experiments that have been in operation in India for the last many years have indicated that they could be used to measure and evaluate the effect of continuous cropping and fertilizer used on soil quality and hence the sustenance of the system. Long-term experiments provide a strong base to measure a sustainable management system in agriculture being records of the past and may serve as an early warning system for the future [71].

\section{Objective of Review}

Under continuous cropping, changes in soil fertility and the resultant crop productivity can be related to nutrient imbalances, which have been recognized as one of the most important factors that limit crop yield. Even the applications of recommended NPK fertilizers, devoid of organic manure have not sustained soil quality. There are so many reports based on the 10-15 years old experiments on the chemical properties from the long term experiments in India and abroad separately, however very scanty information is available in respect of varying nutrient management practices. Keeping in view the importance and very meager information available to evaluate the influence of long-term chemical fertilizers and organic manures on soil fertility:

The above-proposed review will be focused on the following objectives:

i) To identify the advantage and disadvantage of chemical fertilizer and organic manure on soil fertility

ii) To review the long-term effect of chemical fertilizer and organic manure on soil fertility

\section{What Is Fertilizer?}

\subsection{Fertilizer}

Fertilizers are materials containing one or more nutrients elements in the form of chemical compounds of the organic and inorganic nature. These occur either as natural deposits or are synthesized in a chemical factory. Fertilizers are two types (i) Organic Fertilizers (ii) Inorganic (chemical) fertilizers.

\subsubsection{Organic Fertilizers}

Organic fertilizers are natural materials of either plant or animal source, including livestock manure, green manures, crop residues, household waste, compost, and works directly as a source of plant nutrients and indirectly influences the physical, chemical and biological properties of soil [12]. Microorganisms from the soil decay the organic fertilizers to make its nutrients available for utilize by plants [7] which added into the soil and have the characteristic nature of the slow release of nutrients.

\subsubsection{Advantages of Organic Fertilizers}

Organic fertilizers have the following advantages to improve soil fertility:

(i) Increasing organic matter content in soil, improve the soil structure, creating more air space and water retention within the soil and enhances soil nitrogen content, nutrient availability, improves nutrient mobilization [5]. (ii) Organic fertilizer increase root growth due to enhanced soil structure, promoting soil aggregates, enhances cation exchange capacity [57]. (iii) Organic fertilizer acts as a buffering agent against undesirable soil $\mathrm{pH}$ fluctuations [76]. (iv) Organic fertilizers are the fastest-growing sectors of the agriculture and its main objective is to create a balance between the interconnected system such as soil organism, plants, animals and humans [16]. (v) The organic fertilizers offer the biological process necessities of plants and conjointly suppress the plant pests' populations [40] [41]. Organic fertilizers increase the quality and yield of crops [24].

\subsubsection{Disadvantages of Organic Fertilizers}

(i) Organic fertilizers may contain pathogens that are harmful to humans or plants because organic fertilizers are derived from a substance like animal feces or plant/animal matter contaminated with pathogens [26]. (ii) They are relatively low in nutrient content, so larger volume is needed to supply enough nutrients for plant growth. Hence, large-scale agriculture without use inorganic fertilizers it is difficult [125]. (iii) Due to the composition of organic fertilizers highly variable, so that the accurate application of nutrients to plant production is difficult. Also, Microorganisms are required to break down and release nutrients into the soil [26]. (iv) They are also required in large quantities which may not be readily available to small scale farmers [4] [3] when decomposition is slow. However, the decomposition of organic material is strongly affected by temperature and soil moisture thus nutrients may be released when the plant does not need them [67] [91]. (v) The decomposition of organic material is strongly 
affected by temperature and soil moisture thus nutrients may be released when the plant does not need them [67]. (vi) Organic manure contains fecal coliforms, HMs, nutrients that enter water bodies and degrade water quality and poses serious threats to the environments and public health [121] [46]. (vii) Successive application of high rates of dairy manure or sewage sludge can increase the risk of surface and groundwater pollution [66] [90]. The decrease in $\mathrm{P}$ Concentration in organic production system $\mathrm{N}$ and $\mathrm{P}$ present in the manure, accumulate in the soil and may contribute and may increase $\mathrm{NO}_{3}$ - levels in groundwater and eutrophication of surface water[59] [35]. (viii) Application of manure causes the edge of fields nutrient losses if rainfall occurs soon after application [63]. Organic fertilizer increased the water stable extractable and bio-available P content of soil [66].

\subsection{Inorganic Fertilizer}

Nutrients like nitrogen, potassium, and phosphorus are removed by livestock through grazing and crop residue collection. Nutrients consumed by the livestock are recovered through byproducts such as manure. However, the manure is not allowed to recycle back to the farming and grazing lands, due to its alternative uses as fuel [32]. This leads to the degradation of soils which have low nutrients. For soil that much deteriorated, adding chemical fertilizers might be essential because chemical fertilizers can re-establish the soil fertility very quickly and the nutrients are obtainable to the plants as soon as the fertilizers are dissolved in the soil. Inorganic fertilizer increases root residues that mean indirectly increases organic matter [92] [61]. Due to this recently, farmers emphasized chemical fertilizer applications to increase productivity [12].

\subsubsection{Advantages of Inorganic Fertilizer}

(i) The balanced applications of inorganic fertilizer can increase soil organic matter through higher levels of root mass and crop residues [92]. (ii) Inorganic fertilizers can improve the yield of crops [75]. (iii) Inorganic fertilizers increase the soil fertility [27]. (iv) Inorganic fertilizers are good for the rapid growth of plants because the nutrients are already water-soluble, therefore the effect is usually quick and fast, contains all necessary nutrients that are ready to use. Inorganic fertilizers are quite high in nutrient content and only small amounts are required for productivity [39].

\subsubsection{Disadvantages of Inorganic Fertilizer}

(i) The inorganic fertilizer enhances the decomposition of soil organic matter, which leads to degradation of soil structure and decrease in soil aggregation results in nutrients are easily lost from soils through fixation, leaching, gas emission and can lead to diminishing fertilizer efficiency [6]. (ii) Over application of chemical fertilizers can destroy decomposers and other soil organisms, reduce the colonization of plant roots with mycorrhizae and also hazardous to the soil environment [36]. (iii) Inorganic fertilizers accumulates salt which expend more energy to draw water from the soil and cause them to appear wilted or dried out and if there is a rainfall shortly after they are applied them the fertilizers wash away and can pollute streams, ponds, and other water bodies. (iv) The over use of inorganic fertilizers can create a nutrient imbalance and that may causes soil acidity leading to low crop yields [75]. (v) Deficiency of secondary and micronutrients occur in soil and crop if the NPK is consistently used. Continuous use of inorganic fertilizers leads to falling in soil organic matter, increased soil acidity, degradation of soil structure and increased erosion [74].

\section{Results on the Influence of Long-term Chemical Fertilizer and Organic Manure on Soil Fertility}

\subsection{Soil $\mathrm{pH}$ and EC}

Soil Physico-chemical indicators such as soil reaction $(\mathrm{pH})$ electrical conductivity (EC) and CEC influence the solubility of nutrients. It is a function of various kinds of processes that fuelled too by soil biota. Their primary importance in osmotic balances of the plant directly related to water and nutrient uptake. The chemical fertility of soil determines the overall health of the soil, sustainability of crop and it is the index of availability of nutrients to plant. The chemical properties of soil reflect the capacity of soil to provide a congenial chemical and nutritional environment to plant [116]. The chemical fertility supports biological and physical processes in the soil [1]. An increase in $\mathrm{pH}$ with the graded doses of NPK over control [79]. An increased $\mathrm{pH}$ with the incorporation of rice straw but the difference was significant with the application of NPK fertilizer over control in red soils of China [30]. An experiment on Mollisol at Pantnagar found increased $\mathrm{pH}$ by 0.9 to 1.1 units over initial $\mathrm{pH}$ as a result of continuous cropping and fertilizer use for 17 years. The electrical conductivity increased with the application of organic manures [123]. The plots receiving FYM recorded more increase in EC than others; which was due to the release of electrolyte during decomposition [56]. The different fertilizer treatments in a continuous rice-wheat cropping system over 16 years (1987-2003) did not show significant variation in $\mathrm{pH}$ and electrical conductivity of the soil [8] [37]. Similar results were observed by [114] at Pantnagar. Inorganic fertilization caused soil acidification and salinization [132]. The lowest $\mathrm{pH}$ in the surface soil after the wheat crop was registered under control while the highest $\mathrm{pH}$ to the tune of 8.19 was recorded due to $\mathrm{N}_{120}+\mathrm{P}_{40}$ $+\mathrm{K}_{40}+\mathrm{FYM}[21]$. The highest electrical conductivity was 
recorded with the treatment $\mathrm{N}_{120}+\mathrm{P}_{40}+\mathrm{K}_{40}+\mathrm{FYM}$ in surface and sub-surface soil while the lowest electrical conductivity was recorded in control in both surface and sub-surface soil [22].

\subsection{Cation Exchange Capacity}

The addition of organics in combination with chemical fertilizers increased the cation exchange capacity of soil in comparison to control plots [101]. CEC and exchangeable $\mathrm{Ca}^{2+}$ content of the soil improved with the application of organic sources of nutrients either alone or in combination with fertilizers when used over a long period [103][62]. The cation exchange capacity can be used as a good indicator of soil stability, in combination with the organic matter content and the kinds of the exchangeable cation (especially $\mathrm{K}^{+}$and $\mathrm{Na}^{+}$). Long-term $\mathrm{FYM} /$ manure addition increased CEC due to the colloidal nature of organic matter [81]. The cation exchange capacity of soils reduced in almost all the treatments due to continuous use of chemical fertilizers and amendments except 100 percent NPK + FYM wherein the initial status of $12.10 \mathrm{Cmol}\left(\mathrm{p}^{+}\right) \mathrm{kg}^{-1}$ was almost maintained [31]. Continuous cropping for nine years CEC increased in all the treatments over control. However, a larger increase in CEC was observed in the soil which received nutrients in a balanced and integrated form [127]. The application of chemical fertilizers either alone or in conjunction with organic materials increased CEC of the soil significantly over control [93]. The results of the investigation showed that the cation exchange capacity (CEC) of the soil increased significantly over the control due to the application of organic manures in combination with chemical fertilizer [45]. An application of $\mathrm{N}_{180}+\mathrm{P}_{80}+\mathrm{K}_{40}+\mathrm{Zn} \quad(\mathrm{F})+\mathrm{FYM}$ over twenty-nine years favored the highest cation exchange capacity in both the surface and sub-surface soil layer while, lowest cation exchange capacity was recorded in control [21].

\subsection{Soil Organic Carbon}

Soil organic carbon is one of the important soil properties influencing the productivity of the soil. The role of soil organic carbon in maintaining soil fertility and crop productivity has been well recognized from the time immemorial and its maintenance in the soil is of most concern under intensive cropping. Organic carbon provides an account of the availability of plant nutrients. Continuous use of inorganic fertilizers reduced the organic carbon content of soil [129]. The highest organic carbon (1.24 and $0.81 \%$ ) content in both the surface and sub-surface layer was registered due to application of $\mathrm{N}_{180}+\mathrm{P}_{80}+\mathrm{K}_{40}+\mathrm{Zn}(\mathrm{F})+\mathrm{FYM}$ while lowest due to control [22]. An increase in organic matter content was attributed to the direct incorporation of organic matter, better root growth and more plant residue addition [34][50] on the evaluation of long- term fertility trials. Continuous cropping without the application of organic manures caused a decrease in organic carbon [70]. Ten years of continuous intensive rice-wheat cropping under various fertilizer and manure treatment in a Mollisol at Pantnagar, the status of the organic matter went down drastically except in plots receiving single super P and FYM [112]. Continuous application of fertilizers alone and in combination with graded level of FYM for soybean-based cropping system was studied by [8] and reported that highest organic $\mathrm{C}$ status due to the application of higher rate of FYM with a half dose of $\mathrm{N}$ and $\mathrm{P}$ fertilizer [10]. Organic C content increased significantly $\left(6.80 \mathrm{~g} \mathrm{~kg}^{-1}\right)$ in cultivated soil over uncultivated $\left(5.19 \mathrm{~g} \mathrm{~kg}^{-1}\right)$ under the long-term of different cropping systems [102] Assessing the result of long-term fertilizer experiment in various agro-ecological regions of India. A decline in organic carbon as a result of the continuous application of $\mathrm{N}$ fertilizer alone while the balanced use of chemical fertilizer along with organic manure improved organic carbon [110]. The effect of integrated use of chemical fertilizers and farm yard manure in long-term fertilizer experiment in all the treatments, the organic carbon content increased however, a marginal decrease was registered in the $100 \% \mathrm{~N}$ and control plots [106]. Higher organic carbon content in FYM and green manure plots than in the control plots under the rice-wheat cropping system in Haryana [82]. In a twelve-year-old long-term fertilizer experiment, the highest value of organic carbon in the treatment of 100\% NPK + FYM @ $10 \mathrm{t} \mathrm{ha}^{-1}$ under rice-wheat crop rotation was observed [89]. The maximum increase in soil organic carbon content was observed with the integrated use of inorganic fertilizers $(\mathrm{N}+\mathrm{P}+\mathrm{K})$ and organic manure [15]. An increase in organic carbon with organic manure application associated with inorganic fertilizers in the rice-wheat system [18]. Soil organic carbon was a significant general indicator of the amount of biological activity, with the higher soil carbon levels having higher activity. However, the soil carbon fractions were a stronger indicator, with the higher activity being associated with higher levels of the labile soil carbon fraction [68]. It was reported that the incorporation of organic material not only increased crop production but also could slow the rate of soil acidification in agricultural ecosystems [43] [130] [134] [29]. The addition of FYM and integrated use of FYM with chemical fertilizers resulted in significantly higher organic carbon accumulation over inorganic fertilizer alone after harvest of maize under maize-wheat cropping system in an Alfisol [53]. Significantly higher organic carbon content in the treatments where organic manure was incorporated @ $6 \mathrm{t}$ $\mathrm{ha}^{-1}$ along with $\mathrm{N} @ 80 \mathrm{~kg} \mathrm{ha}^{-1}$ and $\mathrm{P}_{2} \mathrm{O}_{5} @ 30 \mathrm{~kg} \mathrm{ha}^{-1}$ as compared to the treatments where N@120 kg ha ${ }^{-1}$ and $\mathrm{P}_{2} \mathrm{O}_{5} @ 30 \mathrm{~kg} \mathrm{ha}^{-1}$ were applied without the addition of organic manure [28]. The increase in soil organic carbon content with the long term use of manure in the rice-wheat system has also been reported by [15]. The Application of organic manures along with chemical fertilizers further increased the organic carbon content of the soil significantly over treatment $\mathrm{T}_{5}$ receiving $100 \% \mathrm{RDF}$ to 
both the season [54].

\subsection{Effect of long-term Fertility on Macronutrients}

The chemical fertility of soil determines the overall health of the soil, sustainability of crop and it is the index of availability of nutrients to plant. Soil chemical fertility is a function of various kinds of processes that occur in the soil biota. The chemical properties of soil reflect the capacity of soil to provide a congenial chemical and nutritional environment to plant [116]. The chemical fertility supports biological and physical processes in the soil [1].

\subsubsection{Available Nitrogen}

Nitrogen is one of the most important plant nutrients. Nitrogen dynamics in the soil are largely affected by the changes in the organic matter content of the soil. Continuous cropping for five years slightly increased the available $\mathrm{N}$ with the use of fertilizer $\mathrm{N}$ in combination with $\mathrm{P}$ and $\mathrm{K}$ fertilizer, however, available $\mathrm{N}$ content of soil significantly increased with green manuring and FYM treatments [129]. Significantly higher available $\mathrm{N}$ in fallow, NPK and N alone plots over control plots and in $100 \%$ NPK + FYM as compared to $100 \%$ NPK treated plots in silty clay loam at Pantnagar after 6 years of intensive cropping [19]. A decrease in available soil $\mathrm{N}$ with an increase in soil depth but it increased with an increase in the doses of NPK fertilizer in aquic Hapludoll soil at Pantnagar [11] [123]. The nutrient changes in long-term rice-wheat rotation observed a significant decline in nitrogen content except in the treatments which had received FYM treatment [17]. The combination of NPK + farmyard manure increased available $\mathrm{N}$ by $6-14 \mathrm{~kg} \mathrm{ha}^{-1}$ the increase in available $\mathrm{N}$ with NPK + FYM was higher in the second year of study, indicating the usefulness of INM for the sustainability of rice-wheat cropping system [105]. Greater N in treatment where FYM was applied along with $100 \%$ NPK than in $100 \%$ NPK alone, which could be due to the optimum microbial population[100]. Significant increase of N in soil receiving NPK every year either alone or in combination with FYM [64][51]. Application of green manure along with 50 percent of the recommended dose of fertilizer resulted in the highest available $\mathrm{N}$ in surface soil [124]. Combined application of 100 percent $\mathrm{NPK}+$ green gram +5.0 t FYM each year resulted in significantly higher available $\mathrm{N}, \mathrm{P}$ and $\mathrm{K}$ in post-harvest soil at the end of six years cycle in a rice-wheat cropping system [52]. Continuous manuring and cropping for 20 years decreased the available $\mathrm{N}$ content of the soil in all the treatments in comparison to its initial status [104]. Continuous application of inorganic fertilizer, FYM and cropping for 41 years significantly increased available $\mathrm{N}$ content and the greatest available $\mathrm{N}$ was recorded under the FYM treated plots while, the lowest value of available $\mathrm{N}$ in control [87]. Long-term manure application along with chemical fertilizers led to significantly higher values of soil available $\mathrm{N}$ compared to other fertilization treatments [55] [21]. The highest available $\mathrm{N}$ was recorded with the treatment $\mathrm{N}_{120}+\mathrm{P}_{40}+\mathrm{K}_{40}+\mathrm{FYM}$ in surface and sub-surface soil while the lowest available $\mathrm{N}$ was recorded in control [22].

\subsubsection{Available Phosphorous}

Continuous cropping of rice-wheat-cowpea for two decades without fertilizers reduced the initial status of Olsen's P by 60 percent but the use of NPK + FYM replenished it by 68 percent [33]. The twelve years old long-term fertilizer experiments comprising fourteen treatments of NPK levels with and without FYM, S, and Zn. The highest value of $\mathrm{P}$ was observed in the treatment of 100 percent NPK +10 t FYM ha ${ }^{-1}$ followed by 100 percent $\mathrm{NPK}+\mathrm{S}+\mathrm{Zn}+\mathrm{FYM}$ in a rice-wheat rotation[89][99]. The addition of organic amendments may increase $P$ availability through competition for phosphorus binding sites, solubilization of poorly soluble pools and increased solution $\mathrm{pH}$ [25]. Long-term fertilizer experiment under rice-wheat system observed that fertilizer treatments had a significant influence on available soil phosphorus after each crop sequence [20]. In the long term fertilizer experiments under AICRP on Long term fertilizer experiments to study changes in soil quality, crop productivity and sustainability at different locations in our country considerable build-up of $\mathrm{P}$ was noticed in $100 \%$ NPK treatments [111]. The integrated nutrient management treatments $50 \% \mathrm{~N}$ through $\mathrm{FYM}+50 \% \mathrm{NPK}$ through fertilizers recorded the highest available $\mathrm{P}$ content in soil [104]. The significant increase in available $P$ has been noticed in the treatments where organic manure @ $6 \mathrm{t}$ $\mathrm{ha}^{-1}$ was incorporated along with $\mathrm{N} @ 80 \mathrm{~kg} \mathrm{ha}^{-1}$ and $\mathrm{P}_{2} \mathrm{O}_{5}$ (a) $30 \mathrm{~kg} \mathrm{ha}^{-1}$ having a mean value of $25.39 \mathrm{~kg} \mathrm{ha}^{-1}$ as compared to the treatments where only N@120 kg ha ${ }^{-1}$ was applied without organic manure and P fertilizer [28]. Continuous application of inorganic fertilizer, FYM and cropping for 41 years significantly increased available $\mathrm{P}$ content and the greatest available $P$ was recorded under the FYM treated plots followed by super optimal dose of NPK fertilizers, respectively, the lowest value of available $\mathrm{P}$ in control [87]. Long-term manure application along with chemical fertilizers led to significantly higher values of soil available P compared to other fertilization treatments [55]. The highest available phosphorus status in soil recorded with the application of $\mathrm{T}_{8}(100 \% \mathrm{NPK}+$ wheat straw $)$ while, the lowest available phosphorus status was noted in control plots [113]. The highest available $\mathrm{P}$ was recorded with the application of $\mathrm{N}_{120}+\mathrm{P}_{40}+\mathrm{K}_{40}+\mathrm{FYM}$ in surface and sub-surface soil as compared to other treatments while the lowest available $\mathrm{N}$ was recorded due to control [22].

\subsubsection{Available Potassium}

In a long-term fertilizer experiment, [115] studied the effect of mineral fertilizers and organic manures on potassium $(\mathrm{K})$ balances and $\mathrm{K}$ release properties under 
maize-wheat-cowpea cropping system on a Typic Ustochrept in New Delhi. The highest and lowest values were obtained in $100 \%$ NPK + FYM and $100 \%$ NP treatments, respectively. The $100 \%$ NPK + FYM treatment showed superiority over all other nutrient management treatments viz.; $100 \%$ NPK, $100 \% \mathrm{NP}+\mathrm{Zn}, 100 \% \mathrm{~N}+\mathrm{Zn}$, etc., in improvement of soil properties and potassium fractions in post-harvest soils whereas intensive fertilization without manure in mono-cropping deteriorated the soil properties viz.; $\mathrm{pH}, \mathrm{EC}, \mathrm{CEC}$ and organic carbon [77]. The available $\mathrm{K}$ content of soil showed an increase with the continuous application of fertilizer $\mathrm{K}$ and organic manures over the initial values [129]. A significant increase in available $\mathrm{K}$ in the soil was reported with the application of inorganic fertilizer but the difference was non-significant with the use of rice straw in the soil [30]. Maximum available K content was recorded with $100 \%$ NPK+FYM followed by $150 \%$ NPK in surface soil after rice-wheat sequence in both the years [20]. The available $\mathrm{K}$ in the soil after 20 cropping cycles was significantly influenced by the application of different treatments. It varied from a minimum of $120 \mathrm{~kg} \mathrm{ha}^{-1}$ under control to a maximum of $167 \mathrm{~kg} \mathrm{ha}^{-1}$ under $50 \%$ NPK through fertilizers $+50 \% \mathrm{~N}$ through FYM [104]. An application of organic manure resulted in a higher build-up of available $\mathrm{K}$ content over chemical fertilizers alone [28]. Continuous application of inorganic fertilizer, FYM and cropping for 41 years significantly increased available $P$ content and the greatest available $\mathrm{K}$ was recorded under the FYM treated plots followed by a super optimal dose of NPK fertilizers, respectively [87]. Combined application of organic manure and inorganic fertilizers significantly increase available $\mathrm{K}$ as compared to other treatments [22].

\subsection{Secondary Nutrients}

Calcium, magnesium, and sulfur are required in relatively larger amounts for good crop growth. Sulfur and magnesium are needed by plants in about the same quantities as phosphorus, and for many plant species, the calcium requirement is greater than that of phosphorus. In multiple cropping systems with higher fertilizer levels, the use of high-analysis fertilizers like urea without secondary and micronutrients would decrease the availability of secondary nutrients like calcium, magnesium, and sulfur in soil and cause the imbalance of nutrients.

\subsubsection{Exchangeable Calcium and Magnesium}

In multiple cropping systems, higher fertilizer levels decreased the availability of calcium and magnesium while the application of FYM increased the levels of exchangeable $\mathrm{Ca}$ and $\mathrm{Mg}$ [84]. The $\mathrm{Ca}$ content was lower in plots receiving a continued application of nitrogen, which may be due to the increased uptake of Ca by crops, induced by nitrogen treatment [69]. A decrease in the exchangeable $\mathrm{Ca}$ and $\mathrm{Mg}$ content of the soil was detected where ammonium sulfate had been used as the source of nitrogen. In the case of the FYM application, there was first a decrease followed by an increase due to the slow mineralization of organic manures [58]. An increase in the $\mathrm{Ca}$ and $\mathrm{Mg}$ status of the soil was found due to the continued application of manure while the addition of $\mathrm{N}$ in soil tended to decrease it [80]. The exchangeable $\mathrm{Ca}$ and $\mathrm{Mg}$ status of continuously fertilized acid soil increased due to the application of lime and FYM [86].

The long-term Integrated Nutrient Management on soil fertility status leads to the increased content of both $\mathrm{Ca}$ and $\mathrm{Mg}$ due to the incorporation of FYM along with fertilizers [14]. The cultivated soils with the application of fertilizer + compost + lime contained a large amount of exchangeable $\mathrm{Ca}$ associated with fertilization and liming [119]. An increase in $\mathrm{Ca}$ and $\mathrm{Mg}$ in $100 \% \mathrm{NPK}+\mathrm{FYM}$ and FYM plots [107]. An increase in exchangeable $\mathrm{Ca}$ and $\mathrm{Mg}$ with the application of FYM [9]. [44] Reported 23 and 31\% increase in the concentration of calcium and magnesium respectively in manured over non manured plots.

\subsection{Effect of Long-term Fertility on Micronutrients}

The available micronutrient content decreases with increasing soil depth in all the treatment plots. The accumulation of micronutrients in the soil profile in $\mathrm{N}_{120} \mathrm{P}_{0} \mathrm{~K}_{0}$ treated plots was slightly lower than the control $\mathrm{N}_{120} \mathrm{P}_{0} \mathrm{~K}_{0}$ treatment. The translocation of micronutrients in the soil profile was up to 45 to $60 \mathrm{~cm}$ layer beyond which the changes were not noticeable. The higher amount of available micronutrients in the soil profile was recovered in NP and NPK treated plots [94]. After 35 years of cropping the $\mathrm{Fe}, \mathrm{Mn}, \mathrm{Zn}$ and $\mathrm{Cu}$ content of the soil was increased in the FYM applied plots [118]. Similarly, [109] Available micronutrients increased with the increase in organic carbon content. In the red sandy clay loam soils of Bangalore, DTPA-extractable $\mathrm{Mn}$ and $\mathrm{Cu}$ declined in the soil irrespective of treatments, while DTPA-Zn increased only in FYM treated plots and DTPA-Fe increased under all the treatments [117]. An available contents of Fe, Mn, $\mathrm{Zn}$, and $\mathrm{Cu}$ in soil increased with the application of FYM or green manure along with NPK as compared to $100 \%$ NPK alone [51]. The availability of $\mathrm{Mn}$ in soil increased significantly with NPK + green manuring than $100 \%$ NPK treatment [126]. After twenty-three years of continuous cropping, there was a drastic reduction in the contents of DTPA- $\mathrm{Zn}, \mathrm{Cu}$ and $\mathrm{Mn}$ at all the levels of $\mathrm{N}, \mathrm{P}$ and $\mathrm{K}$ including control plots, whereas SSP tended to raise the status of available Fe [49]. Similar results were reported by [131] after fourteen years of fertilization and cropping in the maize-wheat system. The micronutrient status in the soil after 3-years of rice-wheat was declined over initial value but the decline was least with FYM followed by green manure [65] [114]. In a rice-wheat-cowpea system at Pantnagar absence or presence of $\mathrm{Zn}$ application with NPK or NPK along with FYM, DTPA extractable Zn (0.60 to 
$\left.2.26 \mathrm{mg} \mathrm{kg}^{-1}\right)$ decreased from the initial value $\left(2.7 \mathrm{mg} \mathrm{kg}^{-1}\right)$ [114]. DTPA-extractable $\mathrm{Zn}, \mathrm{Cu}, \mathrm{Mn}$, and $\mathrm{Fe}$ contents decreased appreciably in almost all the treatments from their respective initial values except the plots treated with Sesbania green-manure along with NPK in which DTPA-Fe increased from its initial level [128]. A 31 years LTFE, on maize-wheat at IARI, consisting of treatments control, $100 \% \quad \mathrm{~N}, \quad 100 \% \quad \mathrm{NP}, \quad 100 \% \quad \mathrm{NPK}, \quad 100 \%$ $\mathrm{NPK}+\mathrm{FYM}$ and $100 \% \mathrm{NPK}+\mathrm{Zn}$. They recorded the highest available $\mathrm{Zn}$ with $100 \%$ NPK+FYM, which was significantly higher than control [13]. DTPA-extractable $\mathrm{Zn}, \mathrm{Cu}, \mathrm{Fe}$ and $\mathrm{Mn}$ content in soil increased with the application of green manures and FYM as compared to 100 percent NPK alone as a chemical fertilizer [52]. DTPA-extractable- $\mathrm{Cu}$ increased with the increase in soil organic carbon content [109]. DTPA extractable $\mathrm{Zn}$ and $\mathrm{Cu}$ with application of 50 per cent $\mathrm{N}$ through FYM and 50 per cent RDF in maize and 100 per cent RDF in wheat under maize-wheat cropping system in an Alfisol, whereas, Fe and $\mathrm{Mn}$ content of soil increased with increasing level of fertilizer in maize-wheat system under soybean-wheat intensive cropping in a Vertisol [85]. The addition of FYM with 100 percent NPK significantly raised the content of $\mathrm{Zn}$ in soil over 100 percent NPK treatment [120]. A general reduction in DTPA-Fe, $\mathrm{Mn}$ and $\mathrm{Zn}$ in comparison to their initial value in most of the treatments except FYM, lime, $\mathrm{Zn}$ and 150 percent NPK treated plots [97]. Crop residue incorporation improves micronutrient availability in soil [47]. An increase in diethylene triamine penta acetic acid (DTPA)-extractable $\mathrm{Fe}, \mathrm{Zn}$, and $\mathrm{Cu}$ with the addition of farmyard manure as well as with the addition of vermin-compost [88]. The available content of $\mathrm{Cu}$ in soil increased with the application of FYM along with NPK as compared to Control [95]. The available $\mathrm{Cu}$ content remained relatively constant in the soil profile. The fertilization regimes only influenced it in the $0-10 \mathrm{~cm}$ soil layer, in which it was highest under MNPK $\left(2.1 \mathrm{mg} \mathrm{kg}^{-1}\right)$, followed by NPK $\left(1.65 \mathrm{mg} \mathrm{kg}^{-1}\right)$, CK $\left(1.64 \mathrm{mg} \mathrm{kg}^{-1}\right)$ and SNPK $\left(1.38 \mathrm{mg} \mathrm{kg}^{-1}\right)$ [108]. Combined application of $\mathrm{N}_{120} \mathrm{P}_{40} \mathrm{~K}_{40}+$ FYMr significantly enhanced the available zinc, iron, manganese, and copper as compared to control [23]. The dynamics of iron $(\mathrm{Fe})$ in long term fertilizer experiment under maize-wheat cropping sequence, in an acidic soil classified as Typic Hapludalfs [96]. An increase in DTPA-Zn in $\mathrm{Zn}$ and FYM treated plots may be due to the application of $\mathrm{Zn}$ in former while in latter due to mineralization of organically bound forms of $\mathrm{Zn}$ in the FYM [98]. The Highest zinc content was recorded with treatment $\mathrm{T}_{8}(100 \% \mathrm{NPK}+\mathrm{FYM})$ as compared to control [78].

\section{Conclusions}

Thus, it may be concluded, from the above literature, that application of NPK along with FYM in rice-wheat cropping system sustained the productivity and improved the soil chemical, properties in comparison to application of NPK fertilizers alone. The physico-chemical properties and soil organic matter play a vital role for the nutrient turn over and long-term productivity of the soil which is enhanced by balanced application of nutrients and manure. Integrated use of fertilizer and FYM improved the overall quality of soil whereas continuous cropping without fertilizer deteriorated the soil health. In the light of above, holistic, systematic and in depth work is warranted to evaluate the influence of long term application of fertilizers and organic and inorganic nutrient management practices on crop productivity, soil health and different soil properties under various agro-climatic conditions; and mechanism/processes involved in long term impact of these practices on ecosystem and environment needs to be pinpointed.

\section{Acknowledgements}

We are grateful for the support and technical assistance from colleagues at Govind Ballabh Pant University of Agriculture and Technology.

\section{REFERENCES}

[1] Abbott LK, Murphy DV (2003). What is soil biological fertility? In: Abbott, L. K. and Murphy, D.V. (eds.) Soil Biological Fertility- A Key to Sustainable Land Use in Agriculture. Kluwer Academic Publisher, the Netherland. p $1-15$.

[2] Acton DF, Gregorich LF (1995). Understanding soil health in the health of our soils: Towards sustainable agriculture in Canada. Lands and Biological Resources Research. Ottawa, Canada. pp. 452-467

[3] Adekiya AO, Ojeniyi SO and Agbede MT. (2012). Poultry manure effects on soil properties, leaf nutrient status, growth and yield of cocoyam in a tropical Alfisol. Nigerian Journal of Soil Science, 22(2): pp 30 - 39.

[4] Agbede OO, Kalu BA. (1995). Constraints of small-scale farmers in increasing crop yield: farm size and fertilizer supply. Nigerian Journal of Soil Science, 11: pp 139 - 159.

[5] Akhtar MJ, Asghar HN, Shahzad K, Arshad M (2009) Role of Plant T. B. Roba DOI: 10.4236/oalib.1104618 9 Open Access Library Journal Growth Promoting Rhizobacteria Applied in Combination with Compost and Mineral Fertilizers to Improve Growth and Yield of Wheat (Triticum aestivum). Pakistan Journal of Botany, 41, 381-390.

[6] Alimi T, Ajewole OC, Awosola O, Idowu EO (2007). Organic and Inorganic Fertilizer for Vegetable Production under Tropical Conditions. Journal of Agricultural and Rural Development, 1, 120-136.

[7] Amujoyegbe BJ, Opabode JT, Olayinka A (2007). Effect of 
Organic and Inorganic Fertilizer on Yield and Chlorophyll Content of Maize (Zea mays L.) and Sorghum Sorghum bicolor (L.) Moench. African Journal of Biotechnology, 6, 1869-1873.

[8] Babhulkar RM, Wandile WP, Badole Balpande SS (2000). Residual effect of long-term application of FYM and fertilizers on soil properties (vertisols) and yield of soybean. Journal of the Indian Society of Soil Science, 48: 89-92

[9] Babu MVS, Reddy CM, Subramanyam A, Balaguravaiah $D(2007)$. Effect of integrated use of organic and inorganic fertilizers on soil properties and yield of sugarcane. Journal of the Indian Society of Soil Science, 55: 161-166

[10] Balloli SS, Rattan RK, Garg RN, Gurchan Singh, Krishna Kumari M(2000). Soil physical and chemical environment as influenced by duration of rice wheat cropping system. Journal of Indian Society of Soil Science, 48: 75-78.

[11] Bansal SK, Omanwar PK, Bhardwaj V (1980). Effect of intensive cropping and fertilization on organic carbon and total and available nitrogen in a soil from Pantnagar. Journal of Indian Society of Soil Science, 28: 519.

[12] Basel N, Sami M (2014). Effect of Organic and Inorganic Fertilizers Application on Soil and Cucumber (Cucumis sativa L.) Plant Productivity. International Journal of Agriculture and Forestry, 4, 166-170.

[13] Behera SK, Singh D (2009). Effect of 31 years of continuous cropping and fertilizer use on soil properties and uptake of micronutrients by maize (Zea mays)-wheat (Triticum aestivum) system. Indian J. Agri. Sci., 79(4): 264-270.

[14] Bellakki, M.A., Badanur, V. P. and Setty, R. A. 1998. Effect of long-term integrated nutrient management on some important properties of a Vertisol. Journal of Indian Society of Soil Science, 46(2): 176-180.

[15] Beri V, Sidhu BS, Bahl G S, Bhatt AK (1995). Nitrogen and phosphorus transformations as affected by crop residues management practices and their influence on crop yields. Soil Use Manage, 11: 51-54.

[16] Berova M, Karanatsidis G, Sapundzhieva K, Nikolova V. (2010). Effect of organic fertilization on growth and yield of pepper plants (Capsicum annuum L.). Folia Horticulturae Ann. 22: pp 3-7.

[17] Bhandari AL, Ladha JK, Pathak H, Padre AT, Dawe D, Gupta RK(2002). Yield and soil nutrient changes in a long-term rice-wheat rotation in India. Soil Science Society of America Journal, 66 : 162-170

[18] Bharambe AP, Tomar A (2004). Direct and residual effect of FYM and inorganic nutrients on rice-wheat cropping system in vertisol. PKV Research Journal, 28: 47-52.

[19] Bhardwaj V (1983). Some soil properties, crop yields and nutrient uptake as affected by intensive cropping and fertilization in the long term fertilizer experiment at Pantnagar. Ph.D. Thesis. Submitted to G.B.P.U.A\&T., Pantnagar, U.S. Nagar (U.P.).

[20] Bhatt B (2012).Effect of long term fertilizer application in rice-wheat system on crop productivity and soil. $\mathrm{Ph}$. D. Thesis submitted to G.B.P.U.A. \& T., Pantnagar, India, 135

[21] Bhatt MK Labanya R, JoshiHC, Pareek N, Chandra R, Raverkar KP (2017). Long-term effects of inorganic fertilizers and FYM on soil chemical properties and yield of wheat under rice-wheat cropping system. ENVIS Himalayan Bulletin, 25: 28-35.

[22] Bhatt MK, Raverkar KP, Labanya R, Bhatt CK (2018). Effects of long-term balanced and imbalanced use of inorganic fertilizers and organic manure (FYM) on soil chemical properties and yield of rice under rice-wheat cropping system. Journal of Pharmacognosy and Phytochemistry, 7(3): 703-708.

[23] Bora R, Pandey PC, Singh DK, Yadav SK, Chilwal A (2018). Assessment of soil fertility status under long term balance fertilizer application on rice (Oryza sativa L.). International Journal of Chemical Studies, 6(5): 1696-1699.

[24] Bulluck LR, Brosius M, Evanylo GK, Ristaino JB (2002). Organic and synthetic fertility amendments influence soil microbial, physical and chemical properties on organic and conventional farms. Applied Soil Ecology, 19(2): pp $147-160$

[25] Cassandra MS, Horwath WR, Scow KM (2008). Effects of chemical fertilizers and different organic manure application on soil $\mathrm{pH}, \mathrm{EC}$, and organic matter content. Journal of Food Agriculture and Environment, 9(4) 739-741.

[26] Chen JH (2008). The Combined Use of Chemical and Organic Fertilizers and/or Biofertilizer for Crop Growth and Soil Fertility. Taichung, Taiwan.

[27] Cooke GW (1982). Fertilizing for maximum yield. Third Edition English Language Book society/Collins. pp 457.

[28] Dhaliwal MK, Dhaliwal SS, Thind HS, Gupta RK (2015). Effect of integrated nutrient management on physio-chemical parameters of soil in rice-wheat system. Agriculture Research Journal, 52(2): 130-137.

[29] Dolling PJ (1995). Effect of lupins and location on soil acid Frication rates. Aust. J. Exp. Agric., 35: 753-763.

[30] Dong W, Zhang H, Dai X, Sun X (2012). Effect of different fertilizer application on soil fertility of paddy soil in red soil region of southern china. 7(9): 44-50.

[31] Dutta J (2009). Long-term effect of chemical fertilizers and amendments on sulphur sorption under maize-wheat system. M.Sc. Thesis, p 125. Department of Soil Science, CSK Himachal Pradesh Krishi Vishvavidyalaya, Palampur, India

[32] Erkossa T, Stahr K, Tabor G (2004). Integration of Organic and Inorganic Fertilizers: Effect on Vegetable Productivity. Soil Science and Land Evaluation, Debre Zeit Agricultural Research Centre, Ethiopia.

[33] Gangwar SP, Nand Ram (1996). Long term impact of fertilizers on the relationship of inorganic forms of phosphorus with its availability and uptake by rice in a Hapludoll soil. Acta Agronomica Hungarica, 44(1): 35-39.

[34] Gathala MK, Kanthaliya PC, Verma A, Chahar MS (2007). Effect of integrated nutrient management on soil properties and humus fractions in the long-term fertilizer experiments. Journal of the Indian Society of Soil Science, 55:360-363.

[35] Gosling P, Shepherd M (2005). Long term change in soil fertility in organic arable farming system in England, with particular reference to phosphorous and potassium. Agriculture Ecosystem and Environment, 105:425-432. 
[36] Gruhn P, Goletti F, Yudelman M (2000). Integrated Nutrient Management, Soil Fertility and Sustainable Agriculture: Current Issues and Future Challenges. International Food Policy Research Institute, Washington DC, USA.

[37] Gupta V, Sharma RS, Vishwakarma SK (2006). Long term of integrated nutrient management on yield sustainability and soil fertility of rice - wheat cropping system. Indian Journal of Agronomy, 51(3): 160-164.

[38] Habern H (1992). System theory as a scientific approach towards organic farming. Biology of Agriculture and Horticulture, 16: 37-52.

[39] Han SH, Young J, Hwang J, Kima SB, Parka B(2016) the Effects of Organic Manure and Chemical Fertilizer on the Growth and Nutrient Concentrations of Yellow Poplar (Liriodendron tulipifera Lin.) in a Nursery System. Forest Science and Technology, 12, 137-143.

[40] Heeb A, Lundegardh B, Ericsson T, Savage GP (2005a). Effects of nitrate- ammonium- and organic-nitrogen-based fertilizers on growth and yield of tomatoes. Journal of Plant Nutrition and Soil Science, 168(1): pp123-129.

[41] Heeb A, Lundegardh B, Ericsson T, Savage GP (2005b). Nitrogen form affects yield and taste of tomatoes. Journal of Science and Food Agriculture, 85: pp 1405-1414.

[42] Hill S (1994). Ecological efficiency system, diversity, conference proceedings, IFOMA: Lincoln University, New Zealand. pp. 302-308.

[43] Huang S, Zhang WJ, Yu XC, Huang QR (2010). Effects of long-term fertilization on corn productivity and its sustainability in an Ultisol of southern China. Agric. Ecosyst. Environ., 138: 44-50.

[44] Iqbal M, Van Es, HM, Hansan A, Schindelbeck RR, Moebivs-Clune BN (2014). Soil Health indicators as affected by long term application of farm manure and cropping patterns under semi arid climates. International Journal of Agriculture and Biology, 16: 242-250.

[45] Jat LK, YV (2017). Short-term Effects of Organic and Inorganic Fertilizers on Soil Properties and Enzyme Activities in Rice Production. International Journal of Current Microbiology and Applied Science, 6(2): 185-194.

[46] Jenkins M, Truman CC, Siragusa GR, Line JE, Bailey JS, Frye JE, Endale DM, Franklin DH, Fisher DS, Sharp RR (2008). Rainfall and tillage effects on transport of fecal bacteria and sex harmones, Science of the Total Environment, 403: 154-163.

[47] Kabirinejad S, Kalbasi M, Hossein A, Hoodaji M, Afyuni M. 2014. Effect of Incorporation of Crops Residue into Soil on Some Chemical Properties of Soil and Bioavailability of Copper in Soil. International Journal of Advanced Biology and Biomediation Research, 2 (11), 2819-2824.

[48] Karlen DL, Mausbach MJ, Doran JW, Cline RJ, Harris RF, Schuman GE (1997). Soil Quality: A Concept, definition and framework for evaluation. Soil Science Society of America Journal, 61: 4-10.

[49] Kumar A, Yadav DS (2005). Influence of continuous cropping and fertilization on nutrient availability and productivity of an alluvial soil. Journal of Indian Society of Soil Science, 53: 194-198.
[50] Kumar A, YadavYS (2003). Use of organic manures and fertiliser in rice (Oryza sativa)-wheat (Triticum aestivum) cropping system for sustainability. Indian Journal of Agricultural Science, 65: 703-707.

[51] Kumar B, Gupta RK, Bhandari AL (2008). Changes after long term application of organic manures and crop residues under rice-wheat system. Journal of Indian Society of Soil Science, 56: 80-85.

[52] Kumar V, Singh AP (2010). Long-term effect of green manuring and farmyard manure on yield and soil fertility status in rice-wheat cropping system. Journal of Indian Society of Soil Science, 58: 409-412.

[53] Kumari G, Thakur SK, Kumar N, Mishra B. (2013) Long term effect of fertilizers, manure and lime on yield sustainability and soil organic carbon status under maize (Zea mays) -wheat (Triticum aestivum) cropping system in Alfisols. Indian Journal of Agronomy, 58 (2): 152-158

[54] Kumari R, KumarS, Kumar R, Das A, Choudhary CD, Sharma RP (2017). Effect of long - term integrated nutrient management on crop yield, nutrition and soil fertility under rice-wheat system. Journal of Applied and Natural Science, 9 (3): $1801-1807$.

[55] Kundu, DK, Mazumdar SP, Ghosh D, Saha AR, Majumdar B, Ghorai AK, Behera MS(2016). Long-term effects of fertilizer and manure application on soil quality and sustainability of jute-rice-wheat production system in Indo-Gangetic plain. Journal of Applied and Natural Science, 8 (4): 1793-1800.

[56] Lakshmi Prasanna V. Evaluation of soil fertility and quality characters of paddy varieties. M.Sc. (Ag.) Thesis submitted to A.P.A.U., Rajendranagar, Hyderabad, 1991.

[57] Lal R (2006). Enhancing Crop Yields in the Developing Countries through Restoration of the Soil Organic Carbon Pool in Agricultural Lands. Land Degradation \& Development, 17, 197-207.

[58] Lal, S. and Mathur, B.S. 1988. Effect of Long term manuring, fertilization and liming on crop yield and physico-chemical properties of acid soils. Journal of Indian Society of Soil Science, 37: 717-724.

[59] Mader P, Fliebback A, Duibois, D, Gunst L, Fried P, Niggli U (2002). Soil fertility and biodiversity in organic farming, Science, 296:1694-1697

[60] Malewar GU (2005). Micronutrient stresses in soils and crops: serious sicknesses and clinical approaches for sustainable agriculture. Journal of Indian Society of Soil Science, 53(4): 484-499.

[61] MatsumotoT, Yamano T (2009). Soil Fertility, Fertilizer and the Maize Green Revolution in East Africa. Policy Working Paper, WPS5158, Japan's National Graduate Institute for Policy Studies and the World Bank Development Research Group Agriculture and Rural Development.

[62] Mehta SC, Grewal KS, Sangwan PS, Dahiya SS (2003). Effect of $\mathrm{pH}$ on cation exchange capacity of soils from semi-arid and humid regions. Annals Biology Hissar, 19(2): $165-168$.

[63] Mishra A, Benham BL, Mostaghimi S (2006). Sediments and nutrient losses from field scale crop land plots treated with animal manure and inorganic fertilizers. Water Air and 
Soil pollution, 175:61-76.

[64] Mishra B, Sharma A, Singh SK, Prasad J, Singh BP (2008). Influence of continuous application of amendments to maize - wheat cropping system on dynamics of soil microbial biomass in Alfisol of Jharkhand. Journal of the Indian Society of Soil Science, 56: 71-75.

[65] Mishra BN, Prasad R, Gangaiah B, Shivkumar BG (2006). Organic manure for increased productivity and sustained supply of micronutrient $\mathrm{Zn}, \mathrm{Cu}$, in a rice -wheat cropping system. Journal of Sustainable Agriculture, 28(1): 55-56.

[66] Mohammadi S, Kalbasi M, Shariatmadari H (2009). Cumulative and residual effects of organic fertilizer application on selected soil properties, water soluble $\mathrm{P}$, Olsen's P sorption index. Journal of Agriculture Science and Technology, 11:487-497.

[67] Morris M, Kelly VA, Kopicki RJ, Byerlee D. (2007). Fertilizer Use in African Agriculture: Lessons Learned and Good Practice Guidelines. Washington, DC: The World Bank. The Rain Forest Area of Nigeria. Applied Tropical Agriculture 5: pp 20-23.

[68] Murphy APS, Estrada JA (2014). Distribution, properties, and Management of Vertisol of India. Advance Soil Science, 8: $151-214$

[69] Muthuvel P, Kandaswamy P, Krishnamoorthy KK (1983). Potassium and calcium contents of soils under long-term fertiliser application. Journal of Indian Society of Soil Science, 27: 186-188.

[70] Nambiar KKM (1985). All India Coordinated Research project on long -term fertilizer experiments and its research achievements. Fertilizer News, 30(4): 56-66.

[71] Nambiar KKM (1994). All India Coordinated Research project on long -term fertilizer experiments and its research achievements. Fertilizer News, 30(4): 42-48.

[72] Nambiar KMM, Abrol IP(1989). Long-term fertilizer experiments in India (1971-82) LTFE Re. Bull., IARI, New Delhi. 101p.

[73] Nyalemegbe KK, Oteng JW, Brempong SA (2009). Integrated Organic-Inorganic Fertilizer Management for Rice Production on the Vertisols of the Accra Plains of Ghana. West Africa Journal of Applied Ecology, 16: 23-33.

[74] Ojeniyi SO. (1981). Effect of long term NPK application on secondary and micronutrient content of cofffea carephora. Pl. soil. 60: pp 477-480.

[75] Ojeniyi SO. (2002). Soil management, national resources and environment. Oke-Ado: Adeniran press. pp 24.

[76] Olaniyi, J.O. and Ajibola, A. (2008) Effects of Inorganic and Organic Fertilizers Application on the Growth, Fruit Yield and Quality of Tomato (Lycopersicon lycopersicum). Journal of Applied Biosciences, 8: 236-242.

[77] Pal B, Pati S, Patra PK, Badole S (2007). Effect of integrated nutrient management on nitrogen dynamics in soil of rice-potato based cropping system. Journal of Applied and Natural Science, 7(2): 652-655.

[78] Patel UK, Tiwari JK (2018). Effect of Organic and Inorganic Fertilizer Nutrients on Yield of Soybean Crop. International Journal of Current Microbiology and Applied Science, 7: pp.
392-396.

[79] Patiram, Laxminarayana K (2006). Effect of integrated use of inorganic and organic manures on soil properties, yield and nutrient uptake of rice in Ultisols of Mizoram. Journal of Indian Society of Soil Science, 54: 120-123.

[80] Patiram, Singh KA. (1993). Effect of continuous application of manure and nitrogenous fertilizer on some properties of acid Inceptisol. Journal of Indian Society of Soil Science, 1993; 41:430-433.

[81] Pernes DA, Tessier D (2004). Soil physical properties affected by long-term fertilization. European Journal of Soil Science, 55(3): 505-512.

[82] Phogat SB, Dahiya IS, Hooda RS, Sangwan NK, Solanki YPS (2004). Studies on residual effect of green manuring and farm yard manure for sustained productivity of rice wheat cropping sequence and on soil health under shallow ground water table condition. Annals of Biology, 20(2): 161-165.

[83] Pierzynski GH, Sims JT, Vance GF (1994). Soils and Environmental quality. Lewis Publishers: Boca Raton. pp. 54-60.

[84] Prasad B, Singh RP (1981). Accumulation and decline of available nutrients with long term use of fertilizers, manure and lime on multiple cropped lands. Indian Journal of Agricultural Science, 51: 108-111.

[85] Prasad J, Karmakar S, Kumar R, Mishra B(2010) Influence of integrated nutrient management on yield and soil properties in maize- wheat cropping system in an Alfisol of Jharkhand. Journal of the Indian Society of Soil Science, 58: 200-204.

[86] Prasad J, Srivastava NC, Mathur BS (1996). Available nutrient status of a continuously fertilised and cropped acid soil. Journal of Indian Society of Soil Science, 44: 171-173.

[87] Ram S, Singh V, Sirari, P (2016). Effect of 41 years of application of inorganic fertilires and FYM on crop yields, soil quality, and sustainable yield index under a rice-wheat cropping systemon mollisols of north India. Communication in Soil Science and Plant Analysis, 47(2): 179-193.

[88] Rathod DD, Rathod PH, Patel KP, Patel KC (2013). Integrated use of organic and inorganic inputs in wheat fodder maize cropping sequence to improve crop yields and soil properties. Archives of Agronomy and Soil Science 59 (11): 1439- 1455.

[89] RavankarHN, Pothare S, Rathod PK, Sarap PA (2004). Soil properties and yield of rice and wheat sequence as affected by long term fertilization. Indian Journal of Agricultural Research, 38(2): 143-146.

[90] Rees HW, Chow L, Zebarth BJ, Xing Z, Toner P, Lavoie J, Daigle E(2011).Effects of supplemental poultry manure applications on soil erosion and runoff water quality from a loam soil water under potato production in northwestern New Brunswick. Canadian Journal of Soil Science, 91: 595-613.

[91] Sarkar S, SR Singh, RP Singh (2003). The Effect of Organic and Inorganic Fertilizer on Soil Physical Condition and the Productivity of Rice-Lentil Cropping Sequence in India. 
Journal of Agricultural Science, 140 (4): pp 419-425.

[92] Scholl L, Nieuwenhuis R (2004). Soil Fertility Management. Agromisa Foundation, Wageningen, Netherlands.

[93] SepehyaS (2011). Effect of integrated nutrient management on Rice-Wheat yield and soil properties in a North-Western Himalayan Region. Indian Journal of Soil Conservation, 38(2): 125-135.

[94] Setia RK, Sharma KN, Rathod RK (2004). Sulphur regime of an arable soil (Typic Ustrochrept) under long term differential fertilization at various growth stages of wheat. Journal of Indian Society of Soil Science, 52(2): 150-155.

[95] Shahid M, Shukla AK, Bhattacharya P, Tripthi R, Mohanty S, Das B, Gautam P, Nayak AK. 2015. Micronutrients (Fe, $\mathrm{Mn}, \mathrm{Zn}$ and $\mathrm{Cu}$ ) balance under long-term application of fertilizer and manure in a tropical rice-rice system. Journal of soilsand sediments, DOI 10.1007/ s 11368-015-1272-6.

[96] Shambavi S, Padbhushan R, Sharma SP, Sharma SK (2016). Dynamics of iron under long-term application of chemical fertilizers and amendments on maizewheat cropping sequence. Journal of Plant Nutrition 39 (6): 804-819.

[97] Shambhavi S (2011). Dynamics of micronutrient cations in soil-plant system as influenced by long-term application of chemical fertilizers and amendments in an acid Alfisol. $\mathrm{Ph}$ D Thesis, p 222. Department of Soil Science, CSK Himachal Pradesh Krishi Vishvavidyalaya, Palampur, India.

[98] Shambhavi S, Kumar R, Sharma SP, Verma G, Kumar S, Sharma K, Sharma RP. 2018. Effect of 36 Years of Continuous Cropping and Fertilization on Productivity, Micro and Secondary Nutrient Status and Uptake by Maize-wheat Cropping System in Western Himalayas. International Journal of Bio resource and stress Management, DOI: HTTPS://DOI.ORG/10.23910/IJBSM/ 2018.9.2.1854b 197-202.

[99] Sharma M (2004). Long term effect of fertilizers and manure on some physical properties of soil and nutrient uptake by wheat. Thesis Master of Science in Agriculture (Soil Science), G. B. P. U. A. \& T. pp 15-20.

[100] Sharma M, Mishra B, Singh R (2007). Long term effects of fertilizer and manure on physical and chemical properties of a mollisol. Joumal of the Indian Society of Soil Science 55: 523-524.

[101] Sharma MP, Balf SV, Gupta DK (2001). Soil fertility and productivity of rice (Oryza sativa)-wheat (Triticum aestivum) cropping system in an Inceptisol as influenced by Integrated Management. Indian Journal of Agricultural. Science 71: 81-86.

[102] Sharma MP, Bali SV (2000). Long-term effect of different cropping systems on physico-chemical properties and soil fertility. Journal of Indian Society of Soil Science 48: 181-183.

[103] Sharma R, Dahiya S, Singh D, Nandal JK, Malik RK(2002). Effect of INM on growth, yield, economics and soil fertility in rice-wheat cropping system. Indian Journal of Fertilizer 5(3): 31-34.

[104] Sharma RP, Kaushal V, Verma G, Sharma SP (2014). Effect of three decade long application of chemical fertilizer and amendments on crop yield under maize - wheat cropping system in an acid alfisol. Journal of Applied and Natural Science 6 (1): 106-109.

[105] Sharma SK, Sharma SN (2002). Integrated nutrient management for sustainability of rice-wheat cropping system. Indian Journal of Agricultural Science72 (10): 573-576.

[106] Sharma SP, Subehia SK (2003). Integrated long-term effects of chemical fertilizers on crops yields, nutrients uptake and soil environment in western Himalayan soils. In: Long-term soil fertility management through integrated plant nutrient supply (Swarup, A., Reddy, D.D. and Prasad, R.N. eds.) IISS, Bhopal, India, pp.125-138.

[107] Sharma U, Subehia SK (2014). Effect of long term integrated nutrient Management on rice (Oryza sativa L.)-wheat (Triticum aestivum L.) productivity and soil properties in north-western Himalaya. Journal ofIndian Society of Soil Science 62(3): 248-254.

[108] Shulan Z, Zhijun Li, Xueyun Y (2015): Effects of Long-Term Inorganic and Organic Fertilization on Soil Micronutrient Status, Communications in Soil Science and Plant Analysis, DOI: 10.1080/00103624.2015.1047843.

[109] Sidhu GS, Sharma B.D. 2010. Diethylenetriamine pentaacetic acid-extractable micronutrients status in soil under a rice-wheat system and their relationship with soil properties in different agroclimatic zones of Indo-gangetic plains of India. Communication of Soil Science and Plant Analysis, 41, 29-51.

[110] Singh GB, Swarup P (2000). Lessons from long-term fertility experiments. Fertilizer News. New Delhi. 45: 13-18 and $21-24$.

[111] Singh M, Wanjari RH (2013). Measures to sustain and restore declined productivity in Alfisols under Long Term Fertilizer Experiments. Indian Journal of Fertilisers 9 (2): 24-32.

[112] Singh NP, Sachan RS, Pandey PC, Bisht PS (1999). Effect of a decade long-term fertilizer and manure application on fertility and productivity of rice-wheat system in a mollisols. Journal of Indian Society of Soil Science 47(1): 72-80.

[113] Singh PP, Pawar Rashmi, Meena R. (2017) Response of integrated nutrient management on yield and chemical properties of soil under rice-wheat Cropping system. International Journal of Chemical Studies, 5(2): 366-369.

[114] Singh VP, Ram N (2007). Relationship of available micronutrients with some chemical properties and their uptake by rice-wheat -cowpea system in a mollisols. Journal of Soil and Crops, 17(2): 191-197.

[115] Srivastava S, Swarup A, Singh D (2002). Effect of long term fertilization and manuring on potassium release properties in a typic ustochrept. Journal of Plant Nutrition and Soil Science 165(3): 352-356.

[116] Stockdale EA, Shefered MA, Fortune S, Cuttle SP (2002). Soil fertility in organic farming systems. Soil Use and Management, 118: 301-30 soils. Current Science 25: 259-260.

[117] Sudhir K, Srikanth K, Jayaprakash SM (2002). Sustained crop production under long term fertilizer use in red soil in India.17th WCSS, 14-21 August 2002, Thailand. 108: 1-10. 
[118] Szalai T, Lehoczky E, Nyarai H, Hollo S, Ksatho P(2002). The available micro-element content of soil in a long-term nutrient supply experiment. Communication in Soil Science and Plant Analysis33: 3251-3260.

[119] Takeda A, Hirafumi Tsukada, Masami Nanzyo, Yuichi Takaku, Toyokazu Uemura, Shunichi Hisamatsu (2005). Effect of Long Term Fertilizer Application on the Concentration and Solubility of Major and Trace Elements in a Cultivated Andisol. Soil Science and Plant Nutrition 51(2):251-260.

[120] Thakur R, Sawarkar SD, Vaishya UK, Singh M (2011). Impact of continuous use of inorganic fertilizers and organic manure on soil properties and productivity under soybeanwheat intensive cropping of a Vertisol. J. Indian Soc. Soil Sci. 59: 74-81

[121] Thurston - Enriquez JA, Gilley JE, Eghball (2005). Microbial quality of runoff following land application of cattle manure and swine slurry. Journal of water and health $3: 157-171$.

[122] Tolanur SI, Badanur VP (2003). Effect of integrated use of organic manure, Green manure and fertilizer nitrogen on sustaining productivity frabi sorghum-chickpea system and fertility of a vertisols. J. Ind. Soc. of Soil Sci. 51:37. Vienna. Biol. Fertil. Soils 3: 45-49.

[123] Tyagi VV (1989). Soil fertility status and physic chemical status of an aquic Hapludoll as influenced by 16 years of continuous cropping and fertilization. Thesis M.Sc. (Ag.) submitted to G. B. P. U. A. and T., Pantnagar. (U. S. Nagar). pp. $10-24$

[124] Urkurkar JS, TewariS, Bajpai RK (2010). Influence of long term use of organic and inorganic manures on soil fertility and sustainable productivity of rice (Oryza sativa) and wheat (Triticum aestivum) in Inceptisols. Indian Journal of Agricultural Science .80(3): 208-212.

[125] Vanlauwe B, Bationo A, Chianu J, Giller KE, Merckx R, Mokwunye U, Ohiokpeh O, Pypers P, Tabo R, Shepherd K, Smaling E, Woomer P (2010). Integrated Soil Fertility Management: Operational Definition and Consequences for Implementation and Dissemination. Outlook on Agriculture, $39,17-24$.

[126] Verma A, Nepalia V, Kanthaliya PC.(2005) Effect of continuous cropping and fertilization on crop yields and nutrient status of a Typic Haplustept. Journal of the Indian Society of Soil Science.53, 365- 368.

[127] Verma CP, Thakur ML, Khurana NP (2010). Integrated effect of organic and inorganic manuring on yield sustainability in long- term fertilizers experiments. Crop Research 21(3): 382-383.

[128] Yadav DS, Kumar A (2009). Long-term effect of nutrient management on soil health and productivity of rice (Oryza Sativa)-wheat (Triticum Aestivum) system. Indian Journal of Agronomy 54(1): 15-23.

[129] Yaduvanshi NPS (2001). Effect of five years of rice-wheat cropping and NPK fertilizers use with and without organic and green manures on soil properties and crop yields in a reclaimed sodic soil. Journal of Indian Society of Soil Science. 49: 714-719.

[130] Zhang J, Qin J Yao W, Bi L, Lai T, Yu X(2009)Effect of long term applicant of manure and mineral fertilizers on nitrogen mineralization and microbial biomass $\mathrm{n}$ paddy soil during rice growth stages. Plant and Soil Environment, 2009; 55(3):101-109.

[131] Zhang M, He Z, Xu Y, Fan T (2008). Long term changes in organic carbon and nutrient of an ultisols under maize-wheat cropping in southest china. Geoderma 118: 167-179.

[132] Zhang X, Sun N, Wu L, Xu M, Bingham IJ, Li Z(2015). Effects of enhancing soil organic carbon sequestration in the topsoil by fertilization on crop productivity and stability: evidence from long-term experiments with wheat-maize cropping systems in China. Science Total Environment, 562 (2016), pp. 247-259.

[133] Zhao J, Zhang R, Xue C, Xun W, Sun L, Xu Y, Shen $\mathrm{Q}(2014)$. Pyrosequencing reveals contrasting soil bacterial diversity and community structure of two main winter wheat cropping systems in China. Microbial Ecology, 67: 443-453.

[134] Zhong WT, Wang W, Huang Q, Shen W (2010). The effects of mineral fertilizer and organic manure on soil microbial community and diversity. Plant Soil, 326: 511-522. 